\title{
The solar house in 1947
}

\author{
A. Denzer \\ Assistant Professor, Department of Civil and Architectural Engineering, \\ University of Wyoming, USA
}

\begin{abstract}
Current explorations of the solar house share a rich underreported history, punctuated by a fascinating but little-known episode in America in 1947. In that year, Your Solar House, a book of 49 designs by prominent architects such as Louis Kahn, Edward Durell Stone, and Pietro Belluschi, was published. Organized by the Libbey-Owens-Ford Glass Company, the project was intended for the public as "a book of inspirations rather than of specific patterns."

What did the 'solar house' mean in the mid-20th century? This research concludes that the concept of a solar house possessed a distinct currency in 1945-47 among professionals and the public, but that Your Solar House architects possessed an impressionistic notion of the solar house, rather than a rigorous set of expectations. As a result, the architects submitted a wide variety of aesthetic responses with little attention to studying solar performance. The project overall failed to provide the solar house movement with any technical advances, nor a clear architectural identity.

This paper also analyzes this project's larger historical significance as an early instance when energy-related concerns became (temporarily) central to the architectural discourse, contrary to the usual portrayal of the solar house movement as a contemporary concern with its origins in the energy crisis of the 1970s, an approach which ignores pioneering experiments of the mid-20th century. This paper also discusses the 1947 exhibition within the larger historical and theoretical context of solar house experiments of the same era.
\end{abstract}

Keywords: architectural history, solar architecture, solar house, sustainable architecture, green architecture. 


\section{Introduction}

The history of the solar house in the $20^{\text {th }}$ century includes a fascinating but littleknown episode in America in 1947. The publication Your Solar House, an exhibition of proposed designs by 49 American architects, was intended to be "finest thing of its kind ever attempted" and carried the promise of "a revolution." At the end of World War II, the concept of the solar house captured the attention of the American public, and this project responded to a "throng" of interested consumers. From a historical perspective, Your Solar House represents a significant event which beckons to be reconstructed and analyzed.

Although Your Solar House was conceived with high aspirations, it ultimately failed to create a community of solar architects or to launch a widespread solar house movement after 1947. Moreover, the 49 designs answered the solar house problem with a rather meek symbolic response, rather than a robust aesthetic or technical experimentalism. Nonetheless, Your Solar House provides an instructive snapshot of the architectural community's conception of the solar house at mid-century, and sheds significant light on larger historical themes.

\section{The program and design process}

\subsection{Findings}

In 1945, the Libbey-Owens-Ford Glass Company initiated the project because they had received "thousands of letters" from prospective home buyers interested in questions such as "how a Solar House should appear" [1]. They originally planned to build a solar house in each of the 48 states, having selected a resident architect to design a house appropriate for each location. (The District of Columbia would be included later.)

The company had high aspirations for the project. C. Dean Lowry, Sales Promotion Manager for Libbey-Owens-Ford, told the participants: "in my humble opinion [it] will be the finest thing of its kind ever attempted in this country and could prove to be invaluable to the entire architectural profession for years to come" [2]. In order to identify an architect in each state "most logical to create a solar house," the company assembled a jury of 30 editors, university deans, and other "key men" from the building industry who made their selections by private ballot.

When the organizers notified the selected architects in August 1945, they did not communicate any specific requirements about the design (other than the graphic formatting instructions for the presentation drawings), as if the concept of a solar house was already fully-formed and well-understood. Later in the design process, the architects would be able to discover by inference what might be expected, as the organizers distributed a Libbey-Owens-Ford brochure entitled Solar Houses: An Architectural Lift in Living, which stated:

Just what is a Solar house? Well, the answer is relatively simple. Fundamentally, it is a house designed to take advantage of solar radiation as an auxiliary source of heat. 
...here are the three fundamental principles of such design:

orientation, large windows and sun control [3].

As the design process continued through 1946, the organizers issued a number of bulletins to the participating architects. Most of these were administrative in nature, but a few may have provided further definition of the solar house problem, to a limited extent. For instance, one bulletin included a booklet entitled The Meaning and Magic of Windows by Dr. Matthew Luckiesh, General Electric's Director of Lighting Research (published by Libbey-OwensFord). Luckiesh [4] proclaimed: "A revolution is taking place. An entire wall of a living room may be of glass." Another bulletin cautioned the architects against the "drapes [being] bunched at each side of the room, thereby covering so much glass area." By contrast, these bulletins did not discuss active systems such as solar water heating, nor any 'technical' passive design issues such as slab thickness or daylight control.

In March 1946, Libbey-Owens-Ford apparently abandoned their plans to build the houses, due to the proposed Wyatt program (which became the Veterans' Emergency Housing Act of 1946 when it was approved in May). They would have expected labor and building materials to become scarce, and a commercial promotion of this nature might appear frivolous and perhaps even unpatriotic. They reoriented their efforts to focus on the publication of the designs. Most of the plans had been submitted by May 1946, and Your Solar House was published by Simon and Schuster after several delays in Fall 1947.

\subsection{Discussion}

Clearly the concept of a solar house possessed a distinct currency in this period among professionals and the public. The "thousands of letters" received by Libbey-Owens-Ford started to arrive after Reader's Digest published "The Proven Merit of a Solar Home" (featuring George Fred Keck) in January 1944. Shortly thereafter, several solar house projects were published in popular publications such as Life and the New York Times, and likewise the 'solar house' label began to appear in professional journals such as Architectural Forum.

Why did the concept of a solar house resonate at this time? First, the energy shortages experienced during World War II prompted a temporary interest in energy-efficiency. Second, technological advances in the glass industry made it feasible for homebuilders in cold climates to use more window area. Specifically, Libbey-Owens-Ford had developed a method for mass-producing an insulated double-glass unit (Thermopane), which provided a better balance between admitting daytime solar heat and minimizing radiative heat loss at night. With the typical pre-war technology of single-pane glass windows, the solar house was simply not practical in cold conditions.

Although the label 'solar house' became widely used, it was applied with a distinct lack of rigor, indicating, from a historical perspective, a movement in its infancy. (It would mature in the 1970s.) For instance, a project by L. Morgan Yost published in Architectural Forum in February 1947, carried that label even though it was a fairly conventional house with features such as southern- 
orientation and shading that simply constituted 'good design' in any era. In total, the architects participating in Your Solar House possessed an impressionistic notion of the solar house, rather than a rigorous set of expectations. Perhaps organizers at Libbey-Owens-Ford were deliberately vague in their use of the label 'solar house' in order to stimulate variety, although in retrospect the solar house movement would have benefited by a stronger aesthetic identity.

Libbey-Owens-Ford saw Your Solar House as part of its larger "research program," which included a series of educational brochures (mentioned above) and sponsorship of scientific experiments. One project that the glass company supported during this period did not produce the desired results. In 1945-46, Purdue University Engineering professor F.W. Hutchinson built two houses side-by-side, identical except for the glazing [5]. The object was to test whether passive solar homes gained more energy during the day than they lost at night. The study concluded that passive solar houses may be net money losers in terms of heating costs, which "must have disappointed" the glass company. Hutchinson ended up having a "skeptical view of solar energy" [6]. Your Solar House editors, however, would misinterpret Hutchinson's conclusions in their enthusiastic introduction, by emphasizing "the seasonal saving that in most localities accompanies the use of large glass areas in south walls." There is no record of Hutchinson's reaction to this characterization, but he would have been justified to be cynical of the distortion of his research for commercial purposes.

\section{The publication}

\subsection{Front matter}

Before the presentation of the 49 designs, Your Solar House included eighteen pages of introductory material, which was meant to address the "thousands of letters" Libbey-Owens-Ford had received from consumers. It was described as "a book of inspirations rather than of specific patterns." The authors described the rationale for the project: during the war "it was plain that a throng of Americans were interested in solar houses ... [if not for wartime restrictions] the company would sell acres more of glass." The basic definition of the solar house resembled the one circulated in earlier brochures (see above), and authors included a rudimentary history of the window. Answers were provided for questions ranging from practical ("Can I get a bank loan on a solar house?") to absurd (“Do you get sunburn in a solar house?").

But what is most remarkable about the introductory material is that LibbeyOwens-Ford included relatively 'technical' information that the architects themselves did not. The front matter explained, for example, diagrams of sun paths and section drawings of proper overhang sizing for summer shading. The introductory material even included an exhaustive description of the development of the Thermopane window, and an explanation of the various problems of rigid and flexible seals. Apparently Libbey-Owens-Ford believed 
that consumers in 1947 could tolerate a degree of technical discussion. By contrast, the architects presented 'non-technical' drawings and descriptions.

\subsection{The designs}

All of the designs seemingly followed the "three fundamental principles" of solar house design that Libbey-Owens-Ford had (indirectly) identified: proper orientation, large windows and sun control. Most of the designers who used south orientation appear to have understood the fundamentals of overhang design to provide shading in summer but admit winter solar gain (although the presentation only included plans and perspectives; no sections or diagrams).

But none of the designs explored more advanced issues of passive solar heating that should have interested a progressive architect in 1947. None addressed, even in general terms, the primary underlying objective of saving energy by reducing mechanical heating and cooling needs. None discussed how they had arrived at the amount of glass area relative to the volume behind it. A number of them seemingly did not grasp the importance of mass storage in the floor, as they placed 'solar' windows on a second story or above a basement without discussing any special type of floor construction. Only one-Robert Law Weed's Florida house - proposed solar water heating; the challenge did not imply a machine-age response.

A significant number of the participants deemphasized the thermal benefits of solar radiation and instead wanted to bring more daylight and openness to the house for aesthetic or even curative reasons. For instance, the Pennsylvania house by Stonorov and Kahn omitted any shading on the east because, according to Kahn: "The percentage of ultra-violet rays (therapeutically beneficial) is greatest in the morning because of the clarity of the atmosphere and could be allowed to penetrate the house." Similarly, Harwell Hamilton Harris argued that "effects of ... lightness and airiness ... are principal reasons why a solar house differs from other houses in looks and feel." These attitudes undoubtedly reflected the influence of modern architects like Le Corbusier and Alvar Aalto, who had argued for the architectural benefits of sunlight since the 1920s.

A few of the designs for warm climates naturally interpreted the solar house differently than most of the others, because there was little need for passive solar heating, and in fact any solar gain would have prompted the need for more mechanical cooling. Harris, designing for Southern California, placed glasswalled bedrooms and living rooms facing north. The Oklahoma house by Henry Kamphoefner did the same. A number of others presented plans that coyly lacked an indication of the orientation, perhaps more subtly registering the same protest as Harris and Kamphoefner. (Some designers may have omitted orientation so that readers could imagine that the design in a variety of lot conditions, as was common in modern housing pattern books, even though it ran contrary to the fundamental solar house ethic.)

But even some of the cold-climate houses were deliberately not optimized for solar exposure. For example, Stonorov and Kahn designed their Pennsylvania project with a relatively square footprint to address construction costs. Stonorov acknowledged: "the oblong ... shapes with major faces towards the south are all 
better for solar heating but not necessarily the most advantageous for construction economy" [2]. Then, as now, environmental concerns stood among a number of other variable factors that might influence an architectural design.

One entry clearly implied a depth of experimentation and creative thought that exceeded the others: the Illinois house by George Fred Keck. Keck had been a pioneer of solar architecture since his 1933 "House of Tomorrow" for Chicago's Century of Progress exposition. He also built several solar houses in the late $30 \mathrm{~s}$ and early 40s, and in fact the Chicago Tribune apparently coined the term "solar house" in 1940 to describe Keck's Sloan house [7]. For Your Solar House, Keck elongated the plan east-to-west with a south-facing glass wall protected by wide eaves and projecting wing walls. The windows included a wood louver system at the top and bottom for natural ventilation, and close reading would reveal that the house also featured a one-inch pool of water on the roof for evaporative cooling. (Keck knew by 1946 that this technique reduced heat transmission through the roof by $80 \%$ [7], but did not discuss this in Your Solar House.)

Significantly, at the same time Keck also designed the Sydney Davies house (built in Fall 1946 near Chicago), which was considerably more sophisticated in its experimental technology. Like his Your Solar House project, Keck's Davies house also featured a wood louver system at the top and bottom of the "solar wall" for natural ventilation, and the same "water-cooled roof." But the Davies house also included a cellular clay tile floor system that circulated forced-air, supplied by a furnace, to create a radiant floor, which would be supplemented by the passive solar effects. When the Davies house was published in Architectural Forum, Keck made several diagrammatic illustrations to indicate how the building would perform, a stark contrast to the 'soft' presentation demanded for Your Solar House.

\subsection{Discussion}

The dichotomy between George Fred Keck's Your Solar House project and his Davies house, both designed in 1946, is historically noteworthy and reflects the conservative nature of the Libbey-Owens-Ford project as a whole. How remarkable: for the built project for an actual site and client, Keck's approach was more experimental than for the demonstration project with few practical constraints. To a degree, this attests to progressive character of Davies the client. But it again indicates that, for Your Solar House, the participating architects implicitly understood that 'technical' issues should be deemphasized for a lay audience, which may have diminished Keck's enthusiasm.

An overview of the 49 designs clearly establishes that a majority of them were not experimental in any sense, making no discernable creative contribution to development of solar house performance. Anyone attempting to use Your Solar House to evaluate the actual technical development of the solar house in 1947 would have come away with a dim view. None of the architects at this time were able say anything remotely specific regarding building performance, either in terms of energy use or occupant comfort. In essence, most of the participants answered the 'solar house' problem with a rather meek symbolic response. 
Perhaps, in the absence of attention to technical issues, Your Solar House architects might have contributed significantly to the aesthetic development of the solar house. But here too the program failed to effect any significant consequences. Certainly, a few of the 'modern' designs would have been considered progressive by the standards of the time, and might have provided a model for future work by giving new expression to a new design problem. But many of the designs were simply conservative recapitulations of traditional themes (with larger windows). For instance, John Gaw Meem's project for New Mexico included adobe walls and exposed pine timbers that were meant to communicate regional identity to a national audience. Victorine and Samuel Homsey's design, they wrote, "indicates its Delaware character" through the use of native stone, irregular eave heights, and window proportions. Readers were left to conclude that the solar house had an indeterminate relationship to modernity and lacked a clear architectural identity.

\section{Analysis}

\subsection{Commercial sponsorship}

Any analysis of the historical meaning of the solar house must consider questions raised by the fact that the 1947 exhibition functioned as a promotional venture for a glass company. Your Solar House architects clearly perceived an (indirect) obligation to promote the company's product in their design, since an increased use of glass was embedded in the very definition of the solar house, although they undoubtedly saw 'good design' as the justification for using glass in a new way. Aside from this deeper-level concordance between a marketing agenda and a creative principle, there is no evidence that the organizers sought to overtly influence the architects for commercial benefit. In a January 1946 bulletin, Libbey-Owens-Ford assured participants: "we have no intention of tinkering with your designs" [2].

Architects of this era would have been quite familiar with the costs and benefits of commercially-sponsored architectural competitions, which "proliferated" in the 1930s and 40s. (An enduring theme in architectural history is that 'paper architecture' flourishes in slow economic times.) Although these programs "clearly threatened" the architectural profession by making free plans available, the American Institute of Architects (AIA) "recognized the value of corporate competitions," particularly for "young, vigorous and ambitious creative architects" [8]. Clearly these relationships were mutually beneficial: corporations like Libbey-Owens-Ford spent money to have their products 'endorsed' by association with leading-edge design, while architects received the prestige of being selected and free publicity for their work.

\subsection{Impact}

Whether Your Solar House had a notable significance in its time is difficult to assess. It is unknown how many copies of the volume were printed and distributed, according to Simon and Schuster. (Used copies are not rare sixty 
years later.) No reviews of the book have been located in period literature. Furthermore, there are no known examples of any of the houses actually having been built, even though Libbey-Owens-Ford asked the architects to have full working drawings available for sale, anticipating orders from prospective homebuilders. The promise of "a revolution" and the "finest thing of its kind ever attempted" apparently was met with a resounding silence.

In retrospect Your Solar House appears to represent an end rather than a beginning. It failed to create a community of solar architects or to launch a widespread solar house movement immediately after 1947. As soon as the energy crisis ended, modern architects (with notable but rare exception) became less concerned with energy conservation and increasingly dependent on mechanical systems [9]. Mies van der Rohe's "all-glass" Farnsworth house (1945-51), which was an utter failure in terms of thermal comfort and energy use but was nonetheless celebrated for its aesthetic qualities, neatly symbolizes the postwar architectural enthusiasm for mechanical heating and cooling.

Evidently only a pair of the Your Solar House architects found his own career trajectory affected by the project. Harris Armstrong's Missouri house "became the fundamental basis for virtually all of homes he designed and published in the following years," according to biographer Andrew Raimist. Pietro Belluschi later served as chairman of the 1957 Living with the Sun competition organized by the Association for Applied Solar Energy. Otherwise, only Keck continued to pursue solar house experiments after 1947. But for him, Your Solar House had been merely a minor interlude, not a stimulus. And for other architects, the 1947 exhibition effectively marked the end of a period of exploration. John Gaw Meem based his New Mexico house on an earlier built project - the Gregg house of 1939 - but never designed another solar house after 1947. Nor, apparently, did any of the other prominent participants: O'Neil Ford, Harwell Hamilton Harris, Louis Kahn, Edward Durell Stone.

\subsection{Historical and theoretical context}

The engineers' approach to the solar house at this time differed considerably from its conception by architects in Your Solar House. By 1947, at least four important scientific experiments on solar houses had been conducted at major universities: the Purdue study (mentioned above); a performance study by the Illinois Institute of Technology (IIT) in 1942-43; and solar houses built by the Massachusetts Institute of Technology (MIT) in 1939 and 1947. While Purdue and IIT explored passive issues and MIT tested active systems, what these projects shared, naturally, was an emphasis on measuring the performance of various strategies. Your Solar House architects, meanwhile, (with the exception of Keck) could only speak in subjective terms about the expected benefits of the solar house.

Thus Your Solar House exemplified the larger historical "schism" (as Sigfried Giedion called it) between architecture and engineering, where the domain of the architect is presumed to exclude 'technical' issues which are solved by engineers. Giedion [10] and many others have interpreted this schism as a tremendous problem for architects, who were at worst reduced to decorators of surfaces. In 1946, one wonders for example how an architect like Keck - who 
had already spent over a decade exploring the technical issues associated with solar heating - would have responded to Libbey-Owens-Ford's bulletin about the receptacle position of draperies.

Your Solar House also exists within a larger historical context, where it is possible to discern a modern international solar house movement begun in 1933 and continuing today, which is given coherence by a shared critical position and a shared experimental approach. (I argue that, because of its ideological nature, the modern solar house should be understood as categorically distinct from premodern houses which responded to solar issues by necessity.) Keck and (to a much lesser extent) Belluschi were the only Your Solar House architects who participated meaningfully in this larger $20^{\text {th }}$-century movement.

\subsection{An anecdote}

Your Solar House influenced architectural history in at least one other respect: it prompted the end of the partnership between Louis Kahn and Oscar Stonorov. According to historian Carter Wiseman, Kahn and Stonorov "were invited to design a solar house as part of a program backed by the Libbey-Owens-Ford Glass Company.... [Anne Tyng] and Kahn took charge of the project. Kahn had begun to feel that he was doing more for the office than Stonorov was, and when a disagreement flared over credit for the final design of the solar house, the two parted ways" [11]. Kahn, working independently, would become one of the most important architects of the $20^{\text {th }}$ century, while Stonorov faded into relative obscurity.

\section{Conclusion}

Poor timing certainly also contributed to failure of Your Solar House to stimulate much interest. Energy conservation had been at the front of homeowners' minds in 1945 when the project was initiated, due to wartime shortages. But by late 1947 the solar house lost its urgency because energy was again cheap and plentiful, and a major theme in architecture after 1947 is the enthusiasm for mechanical heating and cooling.

Thus the evolutionary arc of Your Solar House - from the popular interest that prompted it, to its lack of tangible influence - points to a historical theme of great importance, which recurs in the 1970s and 2000s: that mainstream architectural priorities tend to respond (however symbolically) to energy costs, sometimes assisted by commercial interests.

Moreover, the story of Your Solar House contributes to a larger project that identifies 'the solar house' as a durable critical movement in the 20th century, contrary to the common perception that places its origins in the energy crisis of the 1970s. Future research of other 'episodes' will buttress this conclusion and aid the construction of a larger narrative history of this movement. 


\section{References}

[1] Simon, Maron J., (ed). Your Solar House, Simon and Schuster: New York, 1947.

[2] Stonorov, Oscar, Papers, American Heritage Center, University of Wyoming, Laramie, WY.

[3] Solar Houses: An Architectural Lift in Living, Libbey-Owens-Ford Glass Co.: Toledo, Ohio, 1945.

[4] Luckiesh, Matthew, The Meaning and Magic of Windows, Libbey-OwensFord Glass Co.: Toledo, Ohio, 1945.

[5] Hutchinson, F.W., "The Solar House," Heating and Ventilating, 44, pp. 5559, March 1947.

[6] Laird, Frank N., Solar Energy, Technology Policy, and Institutional Values. Cambridge University Press: New York, 2001.

[7] Boyce, Robert, George Fred Keck, 1985-1980: Midwest Architect, Ph.D. dissertation, University of Wisconsin: Madison, 1986.

[8] Shanken, Andrew M., "Architectural Competitions and Bureaucracy, 1934 1945," Architectural Research Quarterly, 3(1), pp. 43-54, 1999.

[9] Banham, Reyner, The Architecture of the Well-tempered Environment, The Architectural Press: London, 1969.

[10] Giedion, Sigfried, Space, Time and Architecture, Harvard University Press: Cambridge, (5 $5^{\text {th }}$ ed.), 1967.

[11] Wiseman, Carter, Louis I. Kahn: Beyond Time and Style, W.W. Norton: New York, 2007. 